\title{
High impact ionization rate in silicon by sub-picosecond THz electric field pulses
} (Conference Presentation)

Tarekegne, Abebe Tilahun; Iwaszczuk, Krzysztof; Hirori, Hideki; Tanaka, Koichiro; Jepsen, Peter Uhd

\section{Published in:}

Proceedings of SPIE

Link to article, DOI:

$10.1117 / 12.2252058$

Publication date:

2017

Document Version

Publisher's PDF, also known as Version of record

Link back to DTU Orbit

Citation (APA):

Tarekegne, A. T., Iwaszczuk, K., Hirori, H., Tanaka, K., \& Jepsen, P. U. (2017). High impact ionization rate in silicon by sub-picosecond THz electric field pulses (Conference Presentation). In Proceedings of SPIE (Vol. 10102). [101020Z] SPIE - International Society for Optical Engineering. Proceedings of SPIE - The International Society for Optical Engineering https://doi.org/10.1117/12.2252058

\section{General rights}

Copyright and moral rights for the publications made accessible in the public portal are retained by the authors and/or other copyright owners and it is a condition of accessing publications that users recognise and abide by the legal requirements associated with these rights.

- Users may download and print one copy of any publication from the public portal for the purpose of private study or research.

- You may not further distribute the material or use it for any profit-making activity or commercial gain

- You may freely distribute the URL identifying the publication in the public portal 


\title{
High impact ionization rate in silicon by sub-picosecond $\mathrm{THz}$ electric field pulses (Conference Presentation)
}

\author{
Abebe T. Tarekegne, Krzysztof Iwaszczuk, DTU Fotonik (Denmark); Hideki Hirori, Kyoto \\ Univ. (Japan); Koichiro Tanaka, Institute for Integrated Cell-Material Sciences (Japan); Peter \\ U. Jepsen, DTU Fotonik (Denmark)
}

\begin{abstract}
Metallic antenna arrays fabricated on high resistivity silicon are used to localize and enhance the incident $\mathrm{THz}$ field resulting in high electric field pulses with peak electric field strength reaching several MV/cm on the silicon surface near the antenna tips. In such high electric field strengths high density of carriers are generated in silicon through impact ionization process. The high density of generated carriers induces a change of refractive index in silicon. By measuring the change of reflectivity of tightly focused $800 \mathrm{~nm}$ light, the local density of free carriers near the antenna tips is measured. Using the NIR probing technique, we observed that the density of carriers increases by over 8 orders of magnitude in a time duration of approximately $500 \mathrm{fs}$ with an incident THz pulse of peak electric field strength $700 \mathrm{kV} / \mathrm{cm}$. This shows that a single impact ionization process is happening in a time duration of less than $20 \mathrm{fs}$. The measurement is repeated by exciting the sample with an optical pump beam at a wavelength of 400 $\mathrm{nm}$. The optical pump sets the initial free carrier density before the THz-induced impact ionization. The measurements show that the carrier generation mechanism depends on the initial free carrier density which confirms that the carrier generation mechanism is impact ionization, rather than the alternative carrier generation mechanism in high electric field, i.e. Zener tunneling. Finally this technique can be extended to investigate carrier dynamics in other semiconductors.
\end{abstract}

View presentation recording on the SPIE Digital Library: http://dx.doi.org/10.1117/12.2252058.5391659175001 